\title{
SPRR1A wt Allele
}

National Cancer Institute

\section{Source}

National Cancer Institute. SPRR1A wt Allele. NCI Thesaurus. Code C114894.

Human SPRR1A wild-type allele is located within $1 \mathrm{q} 21-\mathrm{q} 22$ and is approximately $2 \mathrm{~kb}$ in length. This allele, which encodes cornifin-A protein, plays a role in keratinocyte differentiation. 